East African Journal of Science, Technology and Innovation, Vol. 2 (4): December 2021

This article is licensed under a Creative Commons license, Attribution 4.0 International (CC BY NC SA 4.0)

\title{
Bivariate Based Susceptibility Mapping for Gully Erosion in Wanjoga River Catchment Upper Tana Basin, Kenya
}

\author{
${ }^{1 *}$ IRERI C., ${ }^{1}$ KRHODA G O., ${ }^{1}$ MUKHOVI M S \\ $1 *$ Department of Earth, Climate and Science, University of Nairobi, Nairobi, Kenya \\ ${ }^{*}$ Corresponding author: ceciliareri@gmail.com
}

\begin{abstract}
Gullies occur in semi-arid regions characterized by rainfall variability and seasonality, increased overland flow, affecting ecological fragility of an area. In most gully prone areas, extent of land affected by gullies is increasing. Thus, predicting susceptibility to gully erosion in semi-arid environment is an important step towards effectively rehabilitating and prevention against gully erosion. Proneness to gully occurrence was assessed against; Land cover/land use, slope, soil characteristics, rainfall variability and elevation, and modelled using geographical information system (GIS)-based bivariate statistical approach. Objectives of the study were; a) to assess influence of geomorphological factors on gully erosion, b) analyze and develop gully erosion susceptibility map, c) verify gully susceptibility images using error matrix of class labels in classified map against ground truth reference data. Total of 66 gullied areas (width and depth $\geq$ ranging 0.5 ), were mapped using $15 \mathrm{~m}$ resolution Landsat images for 2018 and field surveys to estimate susceptibility to gully erosion by Global Mapper software in GIS. The images were verified using 120 pixels of known 15 gully presence or absence to produce an error matrix based on comparison of actual outcomes to predicted outcomes. Influence of conditioning factors to gully erosion showed a significant positive relationship between gully susceptibility and gully conditioning factors with consistency value; $C R=0.097$; value $<0.1$, indicating, individual conditioning factors had an importance in influencing gully erosion. Slope $(43 \%)$ and soil lithotype (25\%), most influenced gully susceptibility, while land cover/land use (12\%) and rainfall $(12 \%)$ had least impact. Verification results showed satisfactory agreement between susceptibility map and field data on gullied areas at approximately $76.2 \%$, an error of positive value of $4 \%$ and a negative value of $7 \%$. Thus, production of susceptibility map by bivariate statistical method represents a useful tool for ending long and short-term gully emergencies by planning conservation of semi-arid regions.
\end{abstract}

Keywords: Susceptibility; Gully; Bivariate; Land cover; GIS

Cite as: Ireri et al., (2021) Bivariate Based Susceptibility Mapping for Gully Erosion in Wanjoga River Catchment Upper Tana Basin, Kenya. East African Journal of Science, Technology and Innovation 3(1).

\section{Introduction}

Gully erosion by overland flow is one of the major dominant and critical sources of sediment in most semi-arid catchment areas of the world (Poesen et al.,2003). Gullies are advanced stages
Received: $\quad$ 07/06/21

Accepted: $\quad$ 13/10/21

Published: $\quad 17 / 12 / 21$ of rills where surface channels have been eroded by overland flow to the point that they cannot be smoothened by normal tillage operations (Poesen et al., 2009; Poesen and Li, 2005). Once gullies are 
initiated and gully network systems are formed, the erosion process is so fast that, they tend to continually grow larger and are difficult and costly to eradicate (Kirkby and Brecken 2009. In short term, gullies can be catastrophic, they are capable of triggering landslides, and damage infrastructure; roads, bridges and buildings since they affect water transfer structure (Frankl et al., 2016; Vandekerckhove et al., 2000; Poesen et al., 2003). In long term, gullies lead to initiation and expansion of semi-arid regions; a threat promoted by soil degradation, large soil loses and changes in steeper and more rugged landscape (Arabameri et al., 2019; Valentin et al., 2005). By changing the slope roughness, the resultant scenario is an ecological fragility in semi-arid regions, which weakens the land's ability to revert to its original condition after degradation.

The alteration ability of gullies to landscape requires agent action to estimate spatial frequency and areas more sensitive to future occurrence of gullies for effective conservation of river catchments (Dube et al., 2014). Consequence, for effective conservation against such phenomenon, appropriate zonation methods and proper knowledge on the potential erosion hazard areas which increase gully susceptibility is inevitable. This requires use of effective and accurate models to determine areas of high risk to gully occurrence.

Numerous studies (e.g.; Poesen, 1998; Nyssen et al., 2006; Hughes and Prosser,2003; Frankl et al.,2012; Kendie et al., 2015; Conoscenti et al.,2014; Abdulfatai et al., 2014; Valentin et al., 2005; Kirkby and Bracken, 2009; Kartz et al.,2013) have carried out studied on gully erosion. Most of these studies have focused on identifying geomorphological and morphological factors that influence gully development (Conoscenti et al., 2014). For instance, in Eastern African region, gully erosion is attributed to increased overland flow resulting from increased degradation of the vegetation cover, as a consequence of overgrazing, intensification of agriculture and poor farming practices associated with encroachment into semi-arid land (Abdulfatai et al., 2014; Nyssen et al., 2002; Sirvio and ReberiroHargrave, 2004). However, factors increasing gully erosion rates in a region and extent to which they contribute to gully severity, and/or the threat they pose to environmental and land use sustainability are higher (Canovas et al., 2017), thus, the mechanisms for estimating future gully occurrence are critical.

Various models have been applied to predict gully erosion (Flanagan and Nearing, 1995; Martínez-Casasnovas, 2003). They include; use of physical based models (i.e.; use of ruler, tapes, pins and differential global positioning system (GPS), which are time consuming, costly and limited in achieving high accuracy over large area (De Vente et al., 2009; Arabameri et al., 2019). Gully modeling approaches provide an opportunity to depict impact of factors influencing gully erosion in a river catchment (Morgan, 1995). To evaluate gully erosion susceptibility in a river catchment, there is need to use simple models with good accuracy and applicable over large areas (Rahmati et al., 2016).

Binary classifications model, a statistical bivariate model analysis, is used to determine effects of gully conditioning factors on gully susceptibility in the study area. The Weight of Evidence Model (WoE) has the potential of modeling gully erosion hazard using available spatial data that can calculate these geomorphic derivatives. The model was chosen due to its capability in predicting size, location, intensity and initiation points, required to predict the effect of intrinsic and extrinsic geomorphic factors on gully formation and finding can be understood and used easily (Lee and Talib, 2005). The model equations are also integrated within the Geographic Information System (GIS) environment and rely on equations which can easily be solved in GIS by use of basic procedures (Magliulo, 2012; Flügel et al.,2003).

Weight of Evidence Model (WoE), a GIS-based bivariate statistical technique (Bonham-Carter et al., 1988) has the potential of modeling gully erosion hazard areas using available satellite spatial data to estimate gully conditioning factors which increase gully susceptibility in an area (Kakembo et al., 2009). WoE model is based on statistical bayesian bivariate approach, originally developed for potential areas of mineral assessment (Bonham-Carter et al., 1988; Agterberg et al., 1990). 
Bivariate statistical method is based on the probability for assessing the relations between the spatial distribution of the areas impacted by gullies and the spatial distribution of the analyzed gully susceptibility factors (BonhamCarter et al., 1994; Barbieri and Cambuli, 2009). Since a gullied area occurs under different environmental and social-economic conditions (Beck et al., 1995), detailed monitoring of gully initiation points, and progressive development of gullies in a variety of environments is paramount. Once gully inventory map is created, a simple binary classification model a statistical bivariate analysis method is used, to determine effects of gully conditioning factors on gully susceptibility in the study area. Use of the model makes it possible to calculate the degree each factor presently and in long-term pose to gully development. The present study assessed the potential of gully erosion susceptibility as a function of geomorphic factors framework and verification of created images within the Weight of Evidence (WoE) framework.

\section{Materials and Methods}

\section{Study area}

The Wanjoga River catchment (Figure 1) covers about $200.4 \mathrm{~km}^{2}$, located in Tana Basin, Embu County, Mbeere North Sub- County. The basin area is between latitude $0^{\circ}, 34^{\prime} 0.48$ south and longitude $37^{\circ}, 42^{\prime} 33.88^{\prime \prime}$ East. Geologically, the area falls into four groups of rocks, the Archaean rocks of the Neoproterozoic rock units which include; the Embu Series, the Tertiary volcanic and superficial deposits of Pleistocene of recent age. Neoproterozoic rock units in this area consist of a wide variety of calcareous rocks, gneisses and schists with the Plagioclase amphibolites and hornblende gneisses most widely spread. Rocky outcrops are common geological features with the most prominent features in the area as the blocks of resistant granitoid gneiss forming the central Kiang'ombe Mountains, the highest physiological unit at $1700 \mathrm{~m}$ above sea level.

The impermeable granitoid gneisses resist weathering and form hills, while the intervening valleys are composed of less resistant and more permeable biotite gneiss, migmatitic gneisses, and banded gneisses (Bear, 1952). Sections such as the top of Kiang'ombe hill, with impermeable granitoid gneisses resist weathering resulting in poorly developed soils (Bear, 1952). At the foot slopes towards the adjoining valleys or plains, soils are arenosols which are deep and well drained. In lowland areas near the Tana River (500m above sea level) with different basement system rocks, soils are stony loam sand to clay cambisols which are well drained. This is the region of dissected erosional plain. 


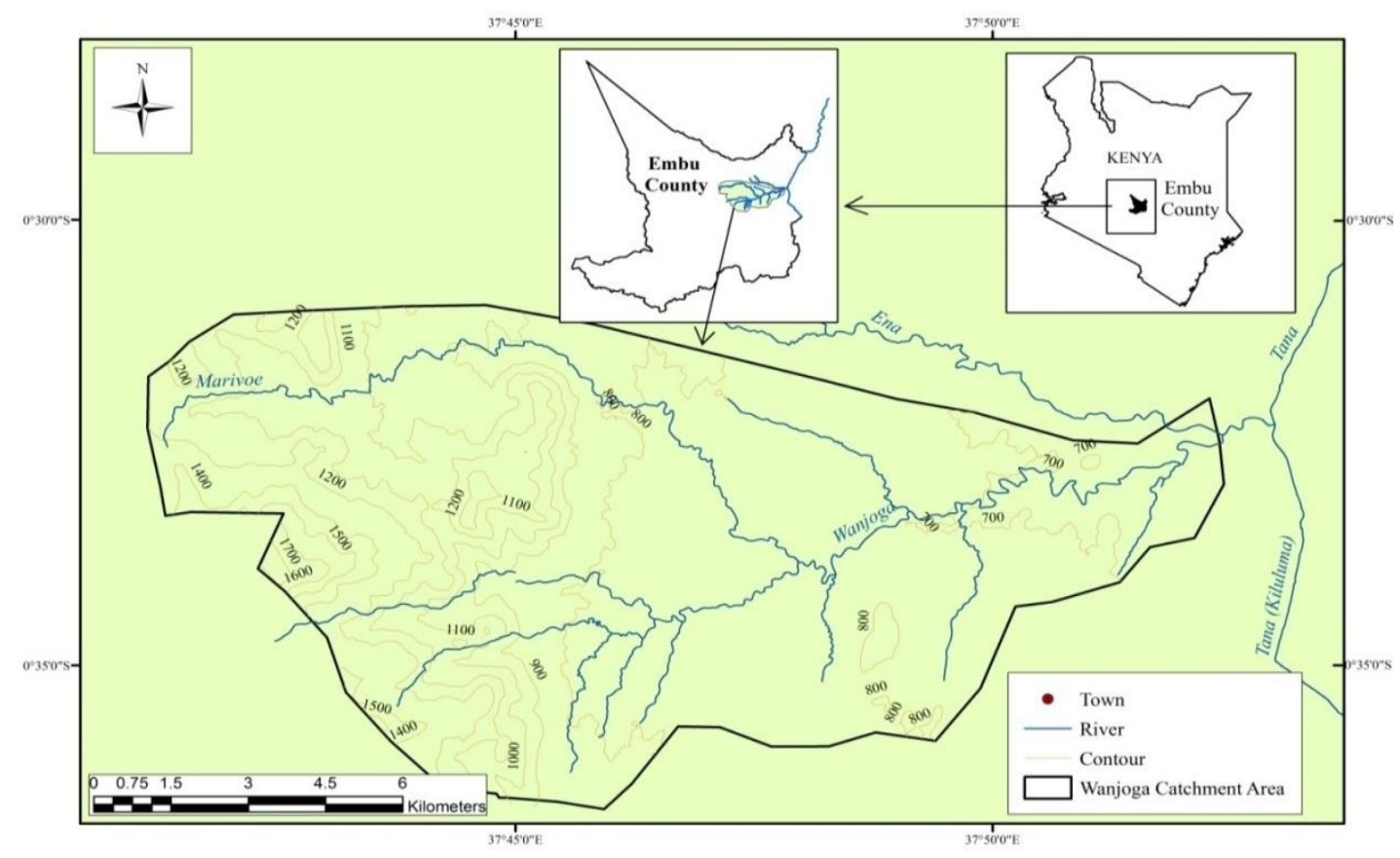

Figure 1. Wanjoga River catchment (Source: Survey of Kenya)

The climate is a semi-arid environment with uneven rainfall distribution between days and months averaging at $650 \mathrm{~mm} /$ per annum. Rainfall patterns are bimodal with $60 \%$ of the total rainfall received between March and May which is longer and more reliable season while $40 \%$ fall in the second rainy season between October and December which is shorter and less reliable season (Jaetzold and Schmidt, 1983). This kind of climate allows only for growth of drought resistant crops and livestock production (GOK, 2013). The upper part of the region which receives higher rainfall, farmers grow drought

\section{Data Collection}

\section{Sources of Data}

Assessment of gully susceptibility and determination of spatial distribution of gullied points in the study area was carried out by use of satellite images and data obtained from field surveys. Gully erosion susceptibility model using gully erosion influencing factors including both erodibility and erosivity variables were adopted for the present study (Flügel et al., 2003). For effective prediction to gully susceptibility, both physical factors which affect the rate and amount of surface runoff which directly cause gully resistant crops such as; cassava, maize, beans, cowpeas, pigeon peas, millet and khat- Catha edulis Forssk., among others (Jaetzold and Schmidt, 1983) with more increased livestock production mainly at the lower regions of the catchment (Ngugi et al., 2011). The objectives of the study were; to assess the influence of geomorphic factors on gully erosion, analyze and develop gully erosion susceptibility and verify gully susceptibility maps by use of an error matrix of cross-tabulation of the class labels in the classified map against ground truth reference data, in a semi-arid environment.

formation (rainfall, soil characteristics and vegetation cover) and factors that can reduce or increase the runoff and its velocity (slope and elevation), must be considered and selected based on availability of data.

Slope and elevation images were generated from a $30 \mathrm{~m}$ resolution Digital Elevation Model obtained from Shuttle Radar Topography Mission (SRTM) satellite. The data was reprojected in ArcGIS 10.4 and clipped to area of study. This formed ranges of the slope which 
later was reclassified into classes of most suitable, moderately suitable and less suitable to gully occurrence.

Land cover images were obtained from Landsat 8 images with resolution $15 \mathrm{~m}$ which were obtained from USGS website. The land cover for the period January and February for the years 2000, 2009 and 2018 were selected to represent periods of uniform rainfall events within the year. The data was transformed to one projection system and processing was performed by supervised classification on Arc Map to create five land cover classes; forest, vegetated, cultivated, bare lands, and water.

Soil data was obtained from published soil surveys (GOK, 1967), at a resolution of 1:50000. Soil classification was based on texture, drainage and depth, factors which influence soil erodibility. Reclassification for drainage resulted into three classes; Lithosols (sandy loam to sandy clay), Arenosols (loam sandy to loam clay) and Combisols (clay loam to clay).

The spatial data like rainfall, obtained in $(x, y)$ point format from the field was plotted in ArcGIS to come up with a raster format using ESRI ArcGIS software showing rainfall variability in the region. Finally, gullies in Wanjoga river catchment were digitized from September 2018 by use of Spot image $1.5 \mathrm{~m}$ resolution made available by Google Earth and ground truthing done for the identified gullies. In addition, 18 field surveys on gullied areas were mapped with GPS map 62s receiver during the field visit and the set used for validation. All datasets were then inputted, processed, layered and reclassified to assign categories and level of susceptibility bases on gully influencing factors as shown on Figure 2.

\section{Data analysis}

Spatial geo-database of the gully features was developed from the field measurements uploaded from a GPS to a desktop GIS. The field data was used for verification of the satellite images. Satellite images for each geomorphological factor (showing; land cover, slope angle, soil type elevation and rainfall variability) were processes into specific raster layers to show influence of variable factors to gully erosion.

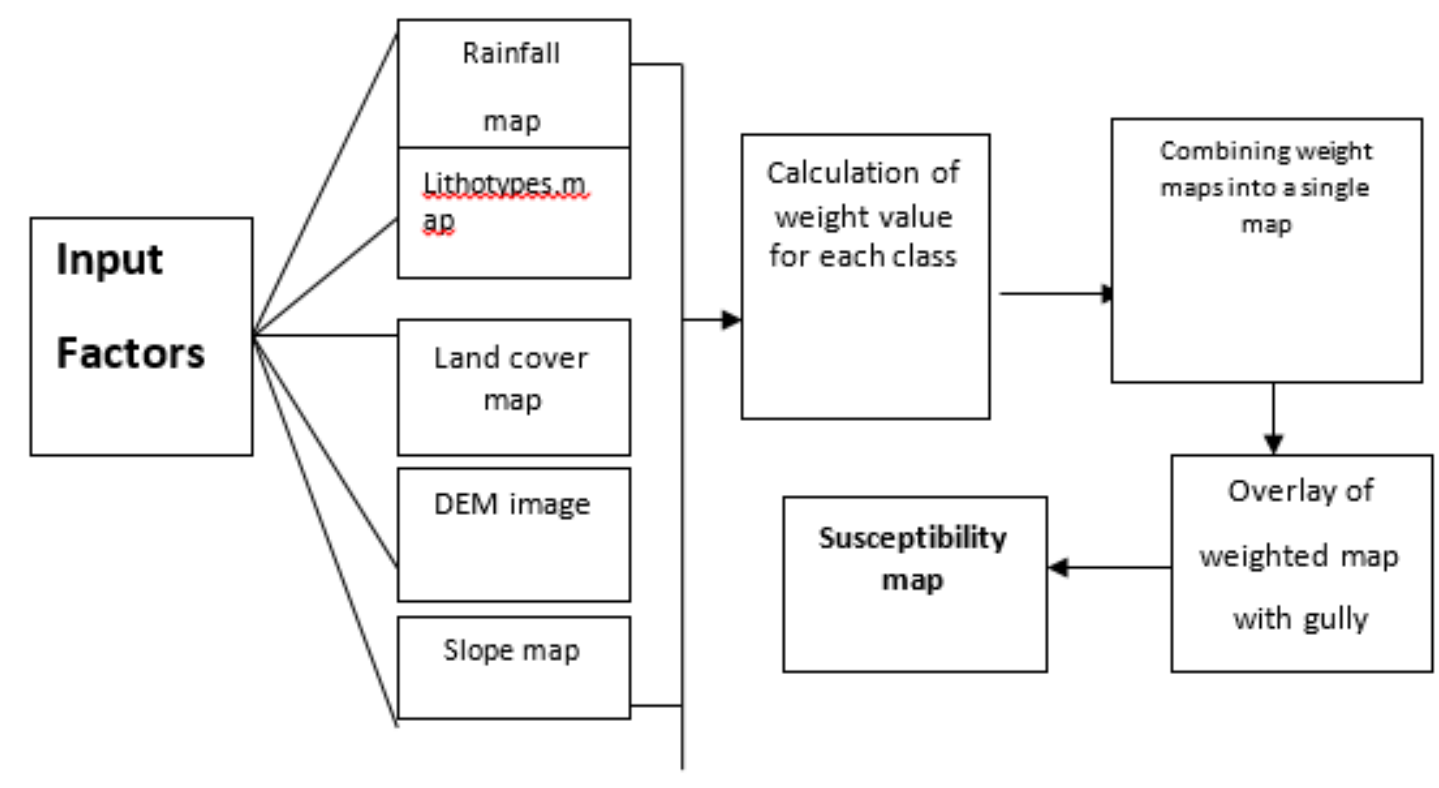

Figure 2. Methodology flowchart to gully erosion susceptibility mapping (Source: Researcher 2021) 
The data in raster layers had weights one to three, value one representing less susceptible while three, representing most susceptible assigned to each parameter depending on its influence. The weighted values re-classify in the input raster into a common evaluation scale of susceptibility and multiply the cell values of each input raster by the raster's weight of importance, it then adds the resulting cell values together to produce the output raster. All factors were combined in Weighted Overlay Tool in ArcGIS 10.4 to form

Weight of Evidence for gully conditioning factors Weight of Evidence (WoE) as applied in the present study is a simple geospatial assessment tool for identifying each influencing factor and the allocation of gullied areas (Bonham-Carter et al., 1988; Kakembo et al., 2009). Single thematic maps (for rainfall variability, soil, land cover, elevation, and slope) are transformed into raster format through ArcGIS software and combined with the gullies inventory map in order to calculate the density of the gully areas for each class of the conditioning factors. Calculated density represents the susceptibility level of the considered gully conditioning factor class (Carrara et al., 1995). The WoE model describes the total number of pixels where gullies occur in relation to total number of pixels in the study area (Lee, 2010). In this model, each gully conditioning factor weight is computed according to the presence or absence of the gullied areas as follows; (Yin and Yan, 1988; Van Westen, 1993)

$\mathrm{Wi}=\frac{\mathrm{NpixSi} / \mathrm{NpixNi}}{\sum \mathrm{NpixSi} / \sum \mathrm{NpixNi}}$

Where;

$\mathrm{Wi}=$ is the weighting value of the class $\mathrm{i}$; NpixSi $=$ is the number of pixels with gullies in the class $\mathrm{i}$; $\mathrm{NpixNi}=$ is the number of pixels in the class $\mathrm{i}$; PNpixSi $=$ is the total number of pixels with gullies in the study area; $\mathrm{PNpixNi}=$ is the total number of pixels in the whole study area.

Finally, the Weighted Overlay Tool in ArcGIS is used to combine the influence for each factor; each factor was assigned a weight depending on the level of influence. The factors were weighted depending on their importance in comparison with one another by dividing number of pixels final susceptibility map as shown on methodological approach (Figure 2). Weight of Evidence has been applied and proved useful in mapping mineral potential areas (Asadi and Hale, 2001; Emmanuel et al., 2000) and landslide susceptibility mapping (Regmi et al., 2010; Lee et al., 2002; Mathew et al., 2007) using GIS. The main disadvantage of the model is that the weight values calculated for different areas are not comparable in terms of the degree of hazard (Regmi et al., 2010).

with gullies in the class by number of pixels in the class. After weighting of the conditioning factors, overlaying of all factors is carried out in ArcGIS to come up with final susceptibility map. By operating the model, the spatial relationships between gully location and each factor's contributing to gully erosion occurrences are derived. WoE is based on the probability for assessing the relations between the spatial distribution of the areas affected by gullies and the spatial distribution of the analyzed gully susceptibility factors (Bonham-Carter et al., 1994; Barbieri and Cambuli, 2009).

\section{Testing verification for WoE model accuracy}

To access the accuracy of the output, use of error matrix was carried out. An error matrix is a standard accuracy reporting mechanism that shows a cross-tabulation of the class labels in the classified map against those in the ground truth reference data. It is used to calculate statistics such as the overall accuracy, producer and user accuracy and the kappa statistic calculated. Once the user and producer accuracy are calculated the Kappa statistic for the gully susceptibility map was calculated since it takes into account the overall statistical agreement of an error matrix (Lu and Weng, 2007). Kappa statistic measures the difference between the actual agreement and the chance agreement and takes into account the whole error matrix using the equation of Congalton, (1991).

$$
\text { Kappa }=\frac{\mathrm{n} \sum_{\mathrm{n}=1}^{\mathrm{k}} \mathrm{n}_{\mathrm{ii}}-\sum_{\mathrm{n}=1}^{\mathrm{k}} \mathrm{n}_{\mathrm{i}+} \mathrm{n}_{+\mathrm{i}}}{\mathrm{n}^{2}-\sum_{\mathrm{n}=1}^{\mathrm{k}} \mathrm{n}_{\mathrm{i}+} \mathrm{n}_{+\mathrm{i}}}
$$

Where:

$\mathrm{n}$ the total number of samples 
nii the number of samples correctly classified into category i

ni the number of samples classified into category $i$ in the classified image

$\mathrm{n}+\mathrm{i}$ is the number of samples classified into category $i$ in the reference data set

The values range from 0 to 1 with values $>0.80$ indicating a positive correlation between classified image and GPS points acquired during the field study the reference data taken by GPS and those ranging from 0.4 to 0.8 representing a moderate level of agreement

\section{Results}

Influence of geomorphic factors on gully erosion Based on created gully conditioning factor layers, the density of the gully areas for each factor was computed symbolizing the weighted level for each factor class and their importance in comparison with one another using a pixel size of $15 \mathrm{~m}$. Positive weighted values indicate that there is positive correlation to the factor and gully erosion in the study area while values cross to zero represent low impact levels.

Table 1. Spatial relations on gully locations and gully conditioning factors

\begin{tabular}{lllllll}
\hline Factor & Class & $\begin{array}{l}\text { Number } \\
\text { of } \\
\text { gullies }\end{array}$ & $\begin{array}{l}\text { Gullies } \\
\%\end{array}$ & NpixNi & NpixSi & Wi \\
\hline Rainfall & $653-900$ & 55 & 83.3 & 681,681 & 22,449 & 0.83 \\
& $901-1,200$ & 11 & 16.7 & 209,590 & 13201 & 1.57 \\
Slope & $<10^{\circ}$ & 20 & 30.3 & 574,530 & 16,695 & 0.73 \\
& $10^{\circ}-20^{\circ}$ & 22 & 33.3 & 238,215 & 11,764 & 1.0 \\
Elevation & $>20^{\circ}$ & 24 & 36.4 & 78,530 & 8,834 & 2.82 \\
& $600-900 \mathrm{msl}$ & 8 & 12.1 & 629,420 & 17,825 & 0.7 \\
& $900-1200 \mathrm{msl}$ & 25 & 37.9 & 135,893 & 13,511 & 2.49 \\
LC & $1200-1800$ & 33 & 50.0 & 125959 & 4,314 & 0.86 \\
& Water body & 0 & 0 & 4,456 & 0 & 0 \\
& Cultivated & 3 & 4.5 & 312.836 & 25 & 0.1 \\
& vegetated & 34 & 51.5 & 359,182 & 23,170 & 0.7 \\
& Forest cover & 8 & 12.1 & 40,731 & 325 & 0.1 \\
Soils & Bare ground & 21 & 31.8 & 174,066 & 12,130 & 0.8 \\
& Lithosols & 7 & 10.6 & 67,630 & 2783 & 1.47 \\
& (sandy) & 14 & 21.2 & 138,532 & 7,559 & 7.0 \\
& Arenosols & 33 & 50.0 & 215,097 & 18,825 & \\
TOTAL & Combisols & 12 & 18.2 & 470,012 & 6,483 & \\
& 50\%clay & & & PNpixNi=891,271 & PNpixSi=35,650 \\
& Combisols (clay & & & & & \\
\hline
\end{tabular}

The density of gullied areas and weighted values reported on Table 1, indicated that, about $4 \%$ (PNpixSi=35,650 pixels out of PnixNi $=891,271$ total pixels) of the study area is covered by gully erosion. Most of these gullies occur in areas influenced at different scale by gully conditioning factors including slope, land cover/land use, soil characteristics and rainfall variability.
Slope factor plays a major role in increasing geomorphic processes which increase susceptibility to gully erosion with steep slopes $>$ $20^{\circ}$, highest susceptible to gully erosion $(\mathrm{Wi}=$ $2.82)$. Areas of moderate slope $\left(10^{\circ}-20^{\circ}\right)$, are affected by increases volume and velocity due to higher concentrate flow $(\mathrm{Wi}=1.00)$ while gentle slope areas (slope angle $<10^{\circ}$ ) are least influences gully susceptibility with weighted values at $\mathrm{Wi}=0.73$, results compare to those of West Bengal, India (Wi = 1.875) (Kumar et al., 2015). A 
significant number of pixels of steep slopes were gullied (NpixSi $=16,695)$ in comparison to gentle slopes though they had low weighted value $(\mathrm{Wi}=0.73)$. The findings march those of Termeh et al., (2020) which conclude, number of gullies increases with increased slope.

Similarly, soil factor portrayed high influence to gully susceptibility based on the high values recorded. Soils with high clay content (Combisols (clay $>50 \%$ ) have highest susceptibility to gully erosion with weighted values at $\mathrm{Wi}=7.53$, showing a higher likelihood to gully erosion compared to other categories, which is consistent with studies of Dube et al., (2014). Though combisols (clay content $>50^{\circ}$ ) covers a limited area (PNpixNi=215,097), it represents a significant number of gullied pixels $(\mathrm{NpixSi}=$ 18,825) with gullied areas. Arenosols and lithosols indicated the least effect on gully susceptibility with values of $\mathrm{Wi}=1.47$ and $\mathrm{Wi}=$ 0.8 respectively. Lithosols are shallow and weakly developed and in some instances with rock outcrops, thus low in gully initiation.

Table 3. Relationship between gullies frequency and gully conditioning factors

\begin{tabular}{|c|c|c|c|c|c|}
\hline Segment category & $\begin{array}{l}\text { Total } \\
\text { gullies }\end{array}$ & $\begin{array}{l}\text { Gullied } \\
\text { area }(\%)\end{array}$ & Main lithotypes & Slope $\left(^{\circ}\right)$ & Elevation (m) \\
\hline $\begin{array}{l}\text { Upper segment } \\
(1200-1800)\end{array}$ & 21 & 51.2 & $\begin{array}{l}\text { Combisols (clay } \\
\text { loam to clay). }\end{array}$ & $>20^{\circ}$ & $1,200-1,800$ \\
\hline $\begin{array}{l}\text { Mid-segment } \\
(900-1200 \mathrm{msl})\end{array}$ & 12 & 29.3 & $\begin{array}{l}\text { Combisols (clay } \\
\text { sandy to clay). }\end{array}$ & $11^{\circ}-20^{\circ}$ & $900-1,200$ \\
\hline $\begin{array}{l}\text { Lower segment } \\
(600-900 \mathrm{~m})\end{array}$ & 8 & 12.1 & $\begin{array}{l}\text { Arenosols(loam } \\
\text { sandy to loam clay) }\end{array}$ & $0^{\circ}-10^{\circ}$ & $600-900$ \\
\hline Total & 66 & 100 & & & \\
\hline
\end{tabular}

The main land covers in the river catchment included; forest cover (thick rain forest and wooded vegetation), vegetation cover (and thickets and bushes), cultivated (different crops), bare land (non-vegetated land, built-up area, road surfaces, rocky outcrops), and water surface (permanent and seasonal rivers, swampy areas, water pans). Bare land is most impacted by gully erosion with weighted value $\mathrm{Wi}=1.7$, since the surface is exposed to raindrop impact. Flow acceleration plays a significant role in increasing processes that result to gully formation. Similarly, vegetated land (mainly used as grazing area) has high impact to gully erosion with weighted values at $\mathrm{Wi}=0.7$.

Contrarily, forested and cultivated land cover are least impacted by gully density with weighted value at $\mathrm{Wi}=0.1$ and 0.1 respectively. Similarly, cultivated land recorded low weighted value $(\mathrm{Wi}=0.1)$, much lower values than those recorded in Mbaire District Zimbabwe (Wi =1.206) (Dube et al., 2014), a factor could be attributed to use of different conservation measures by farmers. Of important to note is a significantly low total number of pixels (PNpixNi $=174,066)$ under bare land though the area had a high number of gullied pixels (PNpixSi $=12,130$ ). Contrarily, cultivated covered a large area $(\mathrm{PNpixNi}=312,836)$ representing $40 \%$ of total pixels, though, the number of gullied pixels is very low $(\mathrm{NpixSi}=25)$ representing low weighted values $\mathrm{Wi}=0.1$.

Rainfall variability significantly influence gully occurrence with areas of low rainfall (653$900 \mathrm{~mm}$ ) more impacted by gully erosion $(\mathrm{Wi}=$ 1.57). Areas of higher rainfall $(901 \mathrm{~mm}-1200 \mathrm{~mm})$ exhibits low weighted value at $\mathrm{Wi}=0.082$. Very similar patterns are witnessed in lower elevated class factor, where higher estimated to gully occurrences are associated with lower elevation 
$(\mathrm{Wi}=2.49)$ compared to upper elevation areas (Wi $=0.7$. Such trends could be influenced by the fact that rainfall and vegetation cover in the area increases with increases in altitude.

\section{Gully erosion susceptibility}

Once weighted evaluation for each class factor was determined, a multi-evaluations ranking for gully erosion conditioning classes was determined against each other.

Based on results on Figure 3, slope and soil lithotype had the highest impact on gully susceptibility accounting for $43 \%$ and $25 \%$ respectively. High susceptible areas occur in slope $>20^{\circ}$ which represent zones of combisols (clay 50\%) lithotype. The region covers the upper segment (1200m - 1800 meters) most impacted by land cover changes (conversion from forest to thickets and bushes) due to encroachment. Land cover and rainfall variability have the least affect to gully susceptibility at $12 \%$ and $5 \%$ respectively.

Table 4. Kappa statistic Error Matrix

\begin{tabular}{lll}
\hline & Actual absence & Predicted presence \\
\hline Actual absence & 110 & 5 (expected gullies) \\
Actual presence & 4 (actual gullies present) & 1 (absent) \\
& & \\
\hline
\end{tabular}

Table 5. Gully Morphological and rate of gully growth

\begin{tabular}{|c|c|c|c|c|c|c|c|}
\hline \multirow[t]{2}{*}{ Gully category } & \multirow{2}{*}{$\begin{array}{l}\text { Gully } \\
\text { parameter }\end{array}$} & \multirow{2}{*}{$\begin{array}{l}\text { Initial } \\
\text { survey } \\
(2000)\end{array}$} & \multirow{2}{*}{$\begin{array}{l}\text { Second } \\
\text { survey } \\
(2009)\end{array}$} & \multirow{2}{*}{$\begin{array}{l}\text { Third } \\
\text { survey } \\
(2021)\end{array}$} & \multicolumn{3}{|c|}{ Rate of gully growth $(\mathrm{m} / \mathrm{yr})$} \\
\hline & & & & & $\begin{array}{l}2000- \\
2009\end{array}$ & $2009-2021$ & $\begin{array}{l}2000- \\
2021\end{array}$ \\
\hline $\begin{array}{l}\text { U-shaped gully } \\
\text { volume } m^{3}\end{array}$ & & 810 & 3,705 & 11,637 & 289.5 & 661 & 515.6 \\
\hline $\begin{array}{l}\text { T-shaped gully } \\
\text { volume }{ }^{3}\end{array}$ & & 3,813 & 10,054 & 33,660 & 624.1 & $1,967.2$ & 1421.3 \\
\hline $\begin{array}{l}\text { V-shaped gully } \\
\text { volume } m^{3}\end{array}$ & & 41.8 & 115.6 & 963.9 & 7.4 & 70.7 & 43.0 \\
\hline
\end{tabular}

Impact of individual variables in relation to gully susceptibility is further emphasized by calculating consistency ratio (CR) in order to measure how consistent, the judgment have been in relation to samples of purely random judgments. If $C R$ is greater than 0.1 , then the judgments is considered untrustworthy and the procedure must be repeated until the preferred value of $C R<0.1$ is obtained. The calculated consistency value $C R=0.097$, which is $<0.1$, an indication that individual variables have a relative importance in influencing gully erosion in the study area. 


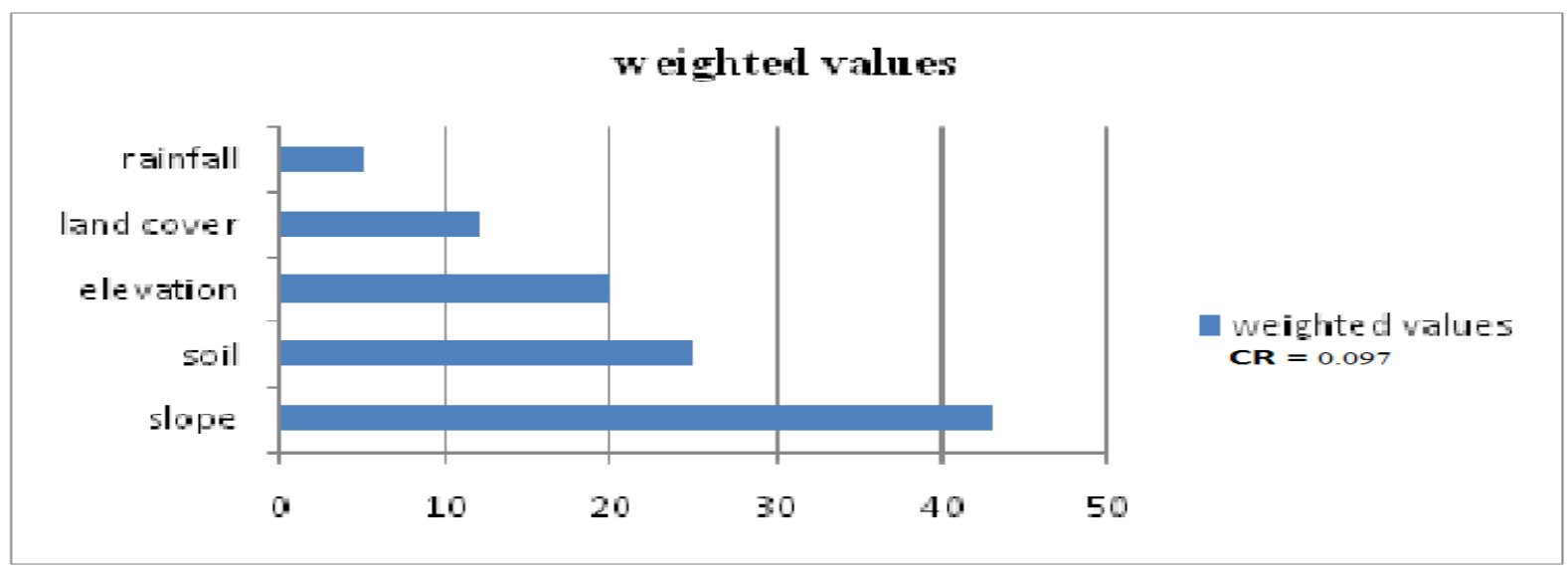

Figure 3. Multi evaluations ranking for gully erosion susceptibility classes on geomorphological factors (Consistency Ratio)

An overlay analysis is then carried out in order to determine the overall summation of the weight of each contributing factor. Use of bivariate statistical (Figure 4), reveals that, $12.73 \%$ of the study area has high susceptibility to gully erosion, $36.32 \%$ is moderate susceptible while low susceptible areas account for $46.95 \%$. High susceptibility areas for gully erosion at upper segment could partly be linked to steep slopes coupled with weakly developed combisols with distinct higher sandy content in the subsoil (Figure 7). This predicted result concurs with field data analysis which reported 51.2\% of gullies observed in the field occur on slopes > $20^{\circ}$ mainly dominated by combisols as reported on Table 2. Moderate risk areas are slopes $\left(11^{\circ}\right.$ $20^{\circ}$ ) accounted for $29.3 \%$ of gullied areas while low risk areas had about $21 \%$ gullied areas observed. These findings are similar to those of Pathak et al., (2005) that concludes that topographic within small catchments is a major factor controlling the spatial variability, location and development of gullies

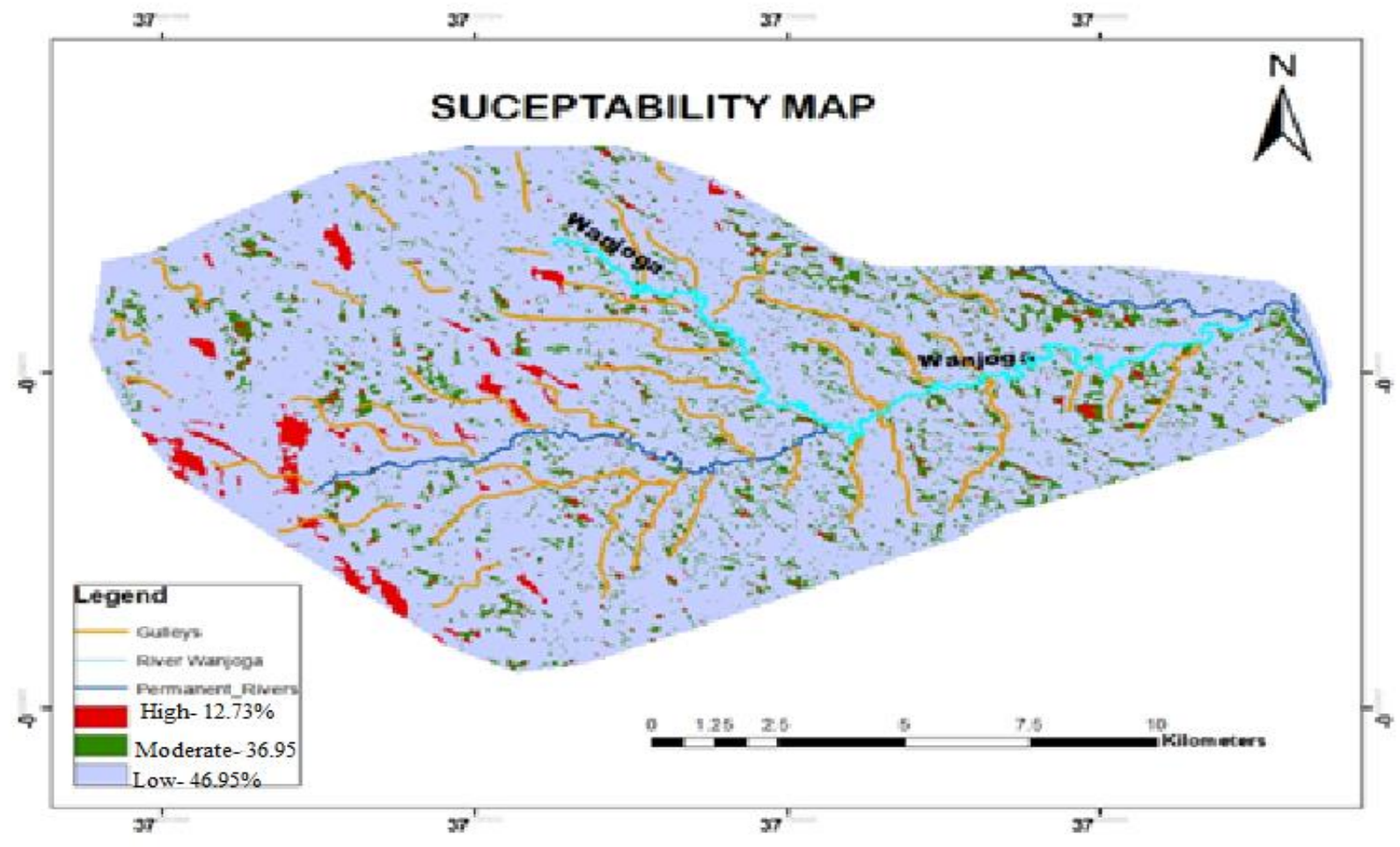


Figure 4. Gully erosion susceptibility in Wanjoga catchment
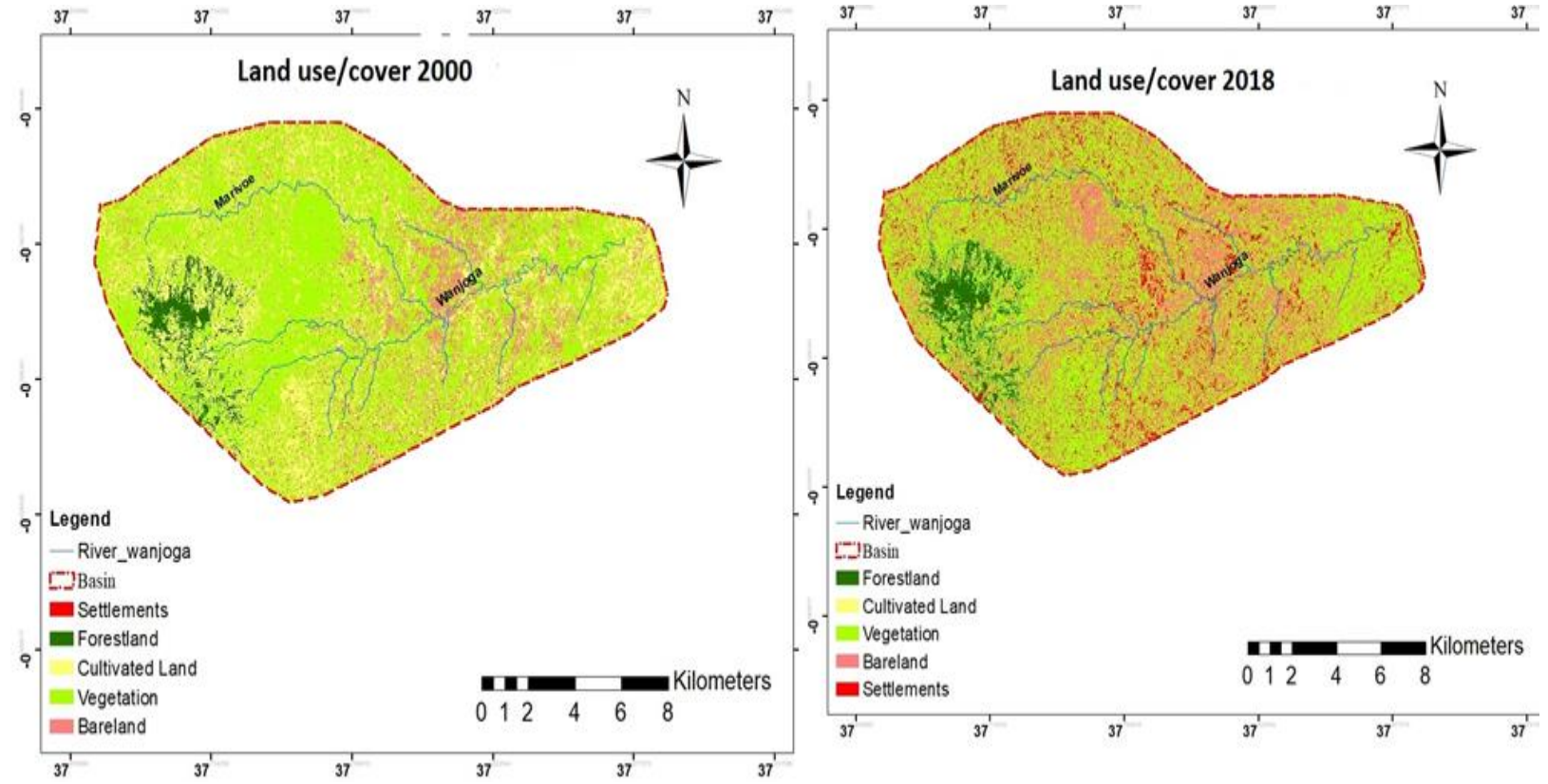

Figure 6. Changes on Land cover/ land use in Wanjoga river catchment from 200-2018

\section{Verification of the gully susceptibility maps}

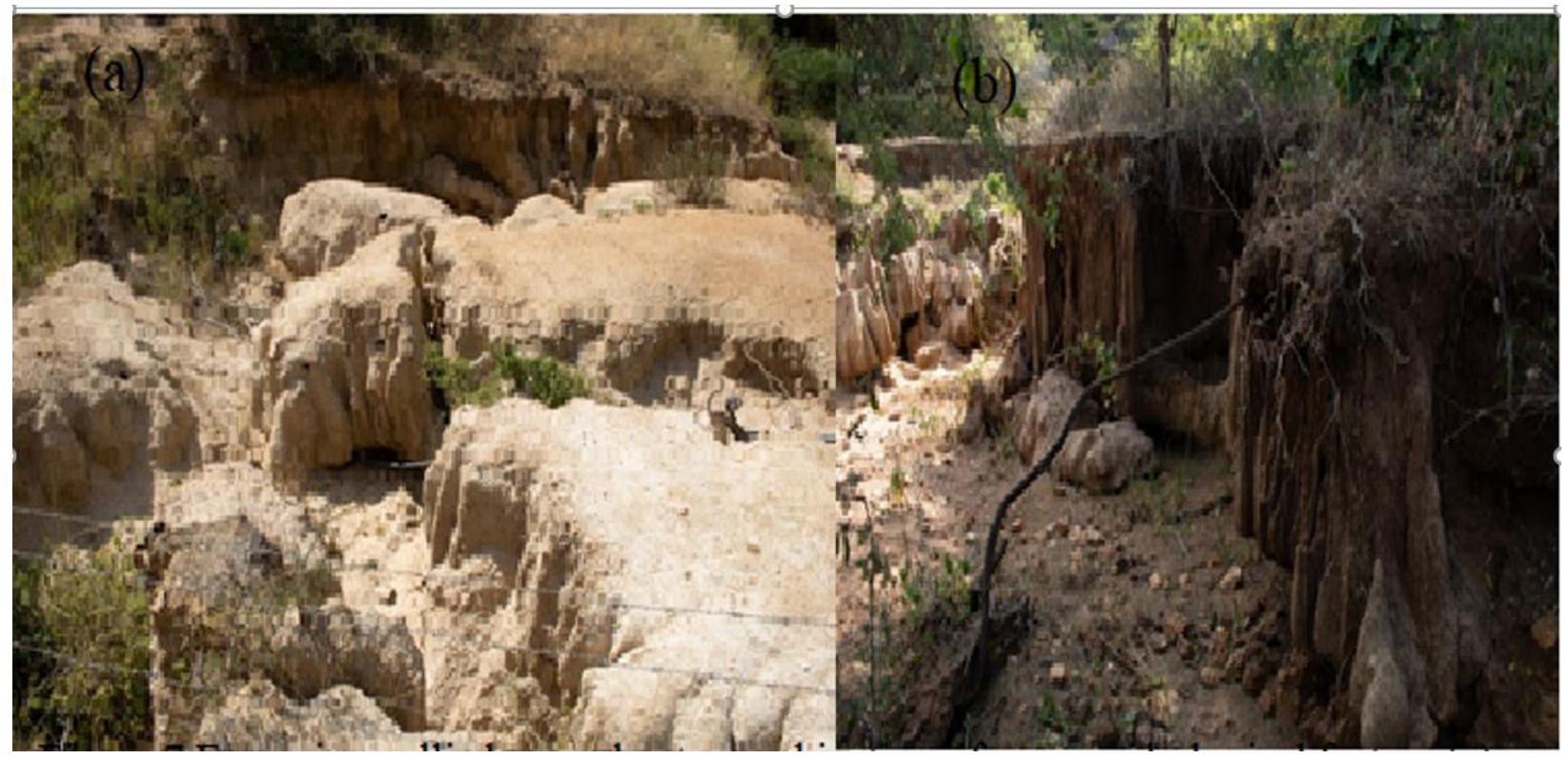

Figure 7. Active gullied areas in different geomorphological regions of the study area

Test verification on satellite images was carried out using an accuracy assessment which assessed the degree of error in the out-put images produced and reported on Table 4. An error matrix is a standard accuracy reporting mechanism that shows a cross-tabulation of the 
class labels in the classified map against those in the ground truth reference data. The verification was carried out using 120 pixels of 15 known gully presence or absence to produce an error matrix based on the comparison actual outcomes to the predicted outcomes developed. The accuracy of the susceptibility image was approximately $76.2 \%$ with false positive value of $4 \%$ and false negative value of $7 \%$. The kappa statistic susceptibility map was at 0.42 representing a low moderate level of agreement, much those of Kumar et al., (2015). The results indicate that some errors are still occurring which could be due to gullies occurring on more vegetated areas which may not be identified in Landsat images resulting in a lower kappa statistic.

\section{Discussion}

In terms of gully frequency, the highest number of gullies occurred on steep slopes while gullies which showed the greatest evolving rates were located at medium and gentle sloping areas (Prosser et al., 2001), and/or brought about by increased discharge due to merging of gullies. The most important factors that led to development of gullies in the study area included; increased concentrate flow due to steep slope, grooves created by movement of animal, regions at boundary of landscape segments, cracks formed by clay soils, animal grazing paths, road discharge points and road cut drainage system.

Determining geomorphological factors that increase susceptibility to gully erosion is an important step towards effective rehabilitation and prevention against gully erosion in a river catchment (Kakembo et al., 2009). Regions of combisols are highly vulnerable to gully erosion since high content of clay mineral, results in highly pulverized soils thus formation of deep, wide cracks when dry, which act as points of concentrate flow. Cracks formed during dry season, act as channelization points through which gully initiation starts (Pulice, et al., 2009). Further, failures and topples enhanced by desiccation cracks in expandable clays, resulting in expanded gullies over time as shown on Table
5 (Rate of growth of T-shaped gullies; $1421.1 \mathrm{~m} / \mathrm{yr})$.

Spatial analysis of the study area showed high density of gullies on steeper slopes, since steeper surfaces increase energy gradient force of water, which increase overland flow velocity, resulting in gully initiation. The results match those of Arabameri et al., (2019), that, elevation and slope have a relationship with gullying. Either, slope determines gully discharge $(Q)$, which affects side slope failures slumping and undercutting (Kartz et al., 2013).

Contrary, presence of thick forest reduces intensity to gully erosion, since plant roots and leaves decrease the erosive action of surface runoff by protecting the soil from overland flow and rain drop impact, under all scenarios. This shows that vegetation plays a significant role in prohibiting gully occurrence and growth, as concluded by Valentin et al., (2005) and Zheng, (2006) that, forested areas experience less gully erosion than bare lands since pant roots have the ability to increase soil shear strength. Similarly, cultivated land are low susceptible to gully erosion (Dube et al., 2014), which could be attributed to use of different conservation measures by farmers.

Importantly, high susceptibility to gully erosion regions were related to extreme combination factors such as presence of steep slopes which may facilitate faster movement of loose surface materials of clay nature (Valentin et al., 2005). Also, steep slopes exposed to land cover changes (Conversion from forest to bushes and bare land) increased by encroachment, are highly susceptible to gully erosion. Devegatation exposes soil to raindrop impact and a possibility to flow concentrating and accelerating resulting to poor soil structures which make soils susceptible to gullying (Conoscenti et al., 2014).

\section{Conclusion}

In conclusion, the results show that both the erodibility factors (land cover, soil lithotype) and erosivity variables (rainfall variability; elevation and slope) have an impact on gully susceptibility in the study area, with slope and soil lithotype having the highest impact to gully development. 
Increasing trends such as land cover changes; brought about by increased anthropogenic activities such as deforestation, road construction, and animal grazing; are likely to continue the prevailing conditions unless efforts geared towards soil conservation are affected.

Thus, the choices of gully conditioning factors together with correct model are able to identify areas most susceptible to gully erosion with the current methodology (bivariate statistical in GIS environment) accurately classifying gullied areas at $76.2 \%$. Such a model can help the decision makers to delineate areas most susceptible to gully development and develop suitable gully rehabilitation and conservation. This study used genialized soil data, thus, further studies are needed in each of soil properties include; soil texture, structure and depth. Further the study suggests use of such model to predict

\section{References}

Abdulfatai, A., Okunlola, A., Akande, G., Momoh, O. and Ibrahim, O. (2014). Review of gully erosion in Nigeria: Causes, Impacts and Possible Solutions. Journal of Geosciences and Geomatics, 2, (3), 125-129

Arabameri, A., Cerda, A. and Tiefenbacher, J. (2019). Spatial pattern analysis and predictionof gully erosion using novel hybrid model of Entropy-Weight of Evidence, 1129.doi:10.3390/w11061129

Arabameri, A., Pradhan, B., Reza, P., Rezaei, K. and Kerle, N. (2018). Spatial modeling of gully erosion using GIS and programing: A comparison among three data mining algorithms; Sci., (8), 1369.

Agterberg, F. and Cheng, Q. (2002). “Conditional independence test for weights-ofevidence modeling," Natural Resources Research, vol. 11, no .4, pp. 249-255.

Barbieri, G. and Cambuli, P. (2009). The Weight of Evidence Statistical Method in Landslide Susceptibility Mapping of the Rio Pardu Valley (Sardinia, Italy), In Proceedings of the 18th World IMACS / susceptibility to gully erosion in other areas which are not semi-arid to confirm its relevance.

\section{Recommendations}

The study recommends use of different conservation structure such; gabions, strip farming, stone barriers, trenches and increasing vegetation cover, that would provide stability on soil movement and impact on gully susceptibility

\section{Acknowledgment}

The authors would like to acknowledge the European Union for sponsoring this study through the through National Drought Management Authority under grant number NDMA/ EDE DRMC/006/2019-2020

MODSIM Congress, held in Cairns, Australia, 13-17 July 2009， p2658 2664.

Bear, M. (1952). A Geological Reconnaissance of the Area S.E of Embu: Geological Survey of Kenya.

Beck, B., Jakeman, J. and McAleer, J. (1995). Construction and evaluation of models of environment systems. In: Beck, M.B., McAleer, M., (Eds.), Modelling Change in environmental Systems. John Wiley and Sons. 3-35

Bonham-Carter, F., Agterberg, P. and Wright, F. (1988). Integration of Geological Datasets for Gold Exploration in Nova Scotia, Photogrammetric Engineering and Remote Sensing, 54, 1585-1592.

Carrara, A., Cardinali, M., Guzzetti, F. and Reichenbach, P. (1995). GIS technology inmapping landslide hazard. In Kluwer, Dordrecht, 135-175

Congalton, G. (1991). A review of assessing the accuracy of classifications of remotely sensed data. Remote sensing of Environment, 37(1), 35-46.

Conoscenti, C., Angileri, S., Cappadonia, C., Rotigliano., Agnesi, V. and Märker, M. (2014). Gully erosion susceptibility 
assessment means of GIS-based logistic regression: A case of (Italy) Elsevier Geomorphology, 204 (2014) 399411

Cánovas, A., Stoffel, M., Martín-Duque, F., Corona, C, Lucía, A., Bodoque, M. and Montgomery, R. (2017) Gully evolution and geomorphic adjustments of badlands to reforestation. Scientific Reports. | 7:45027 | DOI:10.1038/srep45027

De Vente, J., Poesen, J., Govers, G., and BoixFayos, C. (2009). The implications of data selection for regional erosion and sediment yield modeling, Earth Surfaces Processes and Landforms, Vol. 34, p1994-2007.

Dube. F., Nhapi. I., Murwira, A., Gumindoga, W., Goldin, J. and Mashauri, D. (2014). Potential of weight of evidence modeling for gully erosion hazard assessment in Mbire District Zimbabwe. Phys Chem Earth, Parts A/B/C. 67-69:145-152.

Frankl, A., Poesen, J., De Dapper, M., Deckers, J. and Nyssen, J. (2012). Gully head retreat rates in the SemiaridofNorthEthiopia.Geomorphology,173174, 185-195.

Flügel, A., Märker, M., Moretti, S., Rodolfi, G. and Sidorchuk, A. (2003). Integrating geographical information systems, remote sensing, ground truthing and modeling approaches for regional erosion classification of semi-arid catchments in South Africa, Hydrological Processes, 17, 929-942.

G O K, (1967). Geology of the Mount Kenya Area, Degree sheet 44 N.W, Quarter.

G O K, (2014) Agricultural Sector Development Support Program (ASDSP): Ministry of Agriculture Livestock and Fisheries, Nairobi.

Jaetzzold, R. and Schmidt, H. (1983). Farm management handbook of Kenya. Ministry of Agriculture and Livestock Enterprises Kenya.
Hughes, P. and Prosser, P. (2003). Gully and river bank erosion mapping for Murray Darling Basin, CSIRO Land and Water. Canberra Technical Report 3/03 (March 2003)

Jensen, R. (2005) Introductory to digital image processing (3rd Ed.). United States of America: Pearson Prentice Hall.

Kakembo, V., Xanga, W. and Rowntree, K. (2009). Topographic thresholds in gully development on the hillslopes of communal areas in Ngqushwa local municipality, Eastern Cape, South Africa. Geomorphology, 110 (3-4), p188194.

Katz, H., Daniels, J. and Ryan, S. (2013) Slopearea thresholds of road-induced gully erosion and consequent hillslopechannel interactions. Earth surface processes and landforms, 39, 285-295.

Kendie, H., Adugna, B., Gebretsadik, M. and Ayalew, B. (2015). Gully morphology and rehabilitation measures in different agro-ecological environments of Northwestern Ethiopia. Applied and Environmental Soil Science, ID 789479.

Kirkby, J. and Bracken, J. (2009). Gully processes and gully dynamics. Earth Surf Process Landforms 34, 1841-1851.

KNBS, (2019). Kenya integrated household survey. Government of Kenya, Nairobi, Kenya.

http://statistics.knbs.or.ke/nada/index .php/catalog/8/.

Li, Y., Poesen, J. and Valentin, C. (2005). Gully erosion under global change. Second International Symposium on gully erosion, Chengdu, China, May 2002. Sichuan Science and Technology Press, pp. 354.

Lee, S., Choi, J. and Min, K. (2010). Landslide Susceptibility Analysis and Verification

Using the Bayesian Probability Model, Environmental Geology, 43, pp120131 
Martínez-Casasnovas, A. (2003). A spatial information technology approach for the mapping and quantification of gully erosion. Catena, 50, pp293-308.

Magliulo, P. (2012). Assessing the susceptibility to water-induced soil erosion using a geomorphological, bivariate statisticsbased approach. Environmental earth sciences, $67 \quad(6), 1801-1820$.

Morgan, C. (1995). Estimating regional variations in soil erosion hazard in Peninsular Malaysia, Malayan NatureJournal,28(94 106).

Nyssen, J., Poesen, J., Moeyersons, J., Deckers, H., Mitiku, A., and Lang, A. (2004). Human impact on the environment in the Ethiopian and Eritrean highlands: A state of the art. Earth Science Reviews, 64 (34), 273-320.

Ngugi, G., Leonard, E. and Muasya, M. (2011). The Contribution of Forest to Dryland Household Economy: A case of Kiangombe hill forest, Kenya. Ethnobotany. Research and Application, 9, 163-180.

Pathak, P., Wani, P. and Sudi, R. (2005). Gully control in SAT watersheds. Global Theme on Agro-ecosystems, (Report no. 15). Patancheru 502 324, Research Institute for the Semi-Arid Tropics, PP. 28. Andhra Pradesh, India.

Poesen, J. (2011). Challenges in gully erosion research. Landform Analysis, 17, 5-9.

Prosser, P., Rutherfurd, D., Olley, M., Young, J, Wallbrink, J. and Moran, J. (2001). Large scale patterns of erosion and sediment transport in river networks, with examples from Australia. Marine and Freshwater Research, 52, 81-99.

Poesen, J., Vandaele, K., and Van, B. (1998). Gully erosion: importance and model implications. In: Boardman J, Favis, D. (Eds). Modeling soil erosion by water, Springer, 285-311

Rahmati, O., Haghizadeh, A., Pourghasemi, R. and Noor Mohamadi, F. (2016). Gully erosion susceptibility mapping: The role of GIS based bivariate statistical models and their comparison. Nat Hazards. 82(2):1231-1258.

Sirvios, T. and Rebeiro, A. (2004). An overview of gully erosion in Taita Taveta. Expedition report of Department of Geography University of Helsinki, 40,79-86.

Valentin, C., Poesen, J., Yong, J. and Li, C. (2005. Gully erosion: Impacts, factors and control.

www.elsevier.com/locate/catena;

doi:10.1016/j. Catena, 06.001, (63) 132153

Van-Western, J. (2003). Use of Weights of Evidence Modeling for Landslide Susceptibility Mapping. Lecture International Institute for Geography. Information Science and Earth 460

Observation (ITC), Enschede, The Netherlands.

Vandekerckhove, L., Poessen, J., Ostwoud, D., Nachtergaele, J., Kosmas, C., Roxo, J. and Figueiredo, T. (2000). Threshold for gully initiation and sedimentation in Mediterranean Europe. Earth Surface Landforms, 25,12011220.

Yin, J. and Yan, Z. (1988). Statistical prediction model for slope instability of metamorphosed rocks. Proceedings of the 5internationalsymposium on landslides, Lausanne, Switzerland, 2, pp 1269-1272. 